\title{
Human Right to Internet Access in Healthcare in the "Right to Health Concept": Legal Issues
}

\author{
By Oleksandr Shevchuk ${ }^{1}$, Valentyna Zui ${ }^{2}$, Ivanna Maryniv ${ }^{3}$, Svitlana Davydenko ${ }^{4}$, \\ Sergii Mokhonchuk ${ }^{5}$
}

\begin{abstract}
This work reveals the features of the administrative and legal regulation of the human right to access the Internet in the "concept of the right to health". It is emphasized that the basis of the legal regulation of the human right to access the Internet in the "concept of the right to health" should be the recognition of the principles of the priority of human rights and freedoms, adequate state control, ensuring the choice of criteria that make it possible to realize accessibility, anonymity, and minimize the collection and processing of personal data about the patient. The structure of Internet relations in relation to the healthcare sector has been established, their analysis has been carried out, their object has been established. Legal constructions have been formulated: "information", "Internet" in the norms of international and national regulatory legal acts, as well as the terms "e-Health", "electronic cabinet", "electronic medical information system", the author's definition of "the right to access the Internet in the field of health care ". It has been established that the human rights to access the Internet in the "concept of the right to health" should be attributed to the fourth generation of human rights. The concept of "telemedicine" is formulated, their forms are disclosed, the stages of the evolution of legislation are established, and the problems of their legal regulation in the context of human rights are indicated. It is concluded that the consolidation of the right to access the Internet at the level of the Constitution of Ukraine is a necessity.
\end{abstract}

Keywords: human rights, health care, Internet relations, telemedicine, legal regulation

\section{Introduction}

In recent years, more attention has been paid to medical technologies in the world, both in terms of the innovation processes that generate them, and in terms of the methods of their dissemination in health systems [15] especially in the context of human rights. Problems of public health protection and activities to preserve and improve health require constant attention from the state. In modern conditions, a person lives in the space of information technology, Internet use. The quality of life of a person, his health, access to medical services depends on the availability of access to information and digital medical

\footnotetext{
| ${ }^{1}$ Doctor of Juridical Sciences, Professor of the Department of Administrative Law and Administratively Activities, Yaroslav Mudryi National Law University, Kharkiv, Ukraine

${ }^{2} \mathrm{PhD}$ in Law, Associate Professor of the Department of Administrative Law, Yaroslav Mudryi National Law University, Kharkiv, Ukraine

${ }^{3} \mathrm{PhD}$ in Law, Associate professor of the Department of European Union Law, Yaroslav Mudryi National Law

University, Kharkiv, Ukraine

${ }^{4} \mathrm{PhD}$ in Law, Associate Professor of the Department of Criminal Process and Operative Search Activity, Yaroslav Mudryi National Law University, Kharkiv, Ukraine

5Doctor of Juridical Sciences, Professor of the Department of of Criminal Law №1, Yaroslav Mudryi National Law University, Kharkiv, Ukraine
} 
technologies. Law as a system of legal norms should provide an adequate response to these changes in the form of appropriate regulatory regulation. As a result of all these possibilities, a person has new rights that did not exist until now. Such rights are referred to as the "fourth generation" of human rights. The rights of the fourth generation of a person include all rights that have arisen as a result of scientific progress, the development of morality, namely all the so-called "somatic rights", as well as information rights. In Ukraine, human and civil rights and freedoms are realized and guaranteed in accordance with the norms and principles of international law. One of these inalienable rights is the right to health care and medical care. The Constitution of Ukraine guarantees every citizen the right to health care, medical care and medical insurance (art. 49). The state must create conditions for effective and affordable medical care for all citizens [5]. However, the legal mechanisms for ensuring human rights to health care in Ukraine need to be improved, especially the human right to access the Internet in the health sector.

The human right to access the Internet has been actualized in the 21-st century. According to analytical studies by "We Are Social" and "Hootsuite", the total number of Internet users at the beginning of 2020 in the world is already more than 4.5 billion people, which is $7 \%$ more than last year. This is almost $60 \%$ of the world's population. More than 5.19 billion people use mobile phones, and the number of users has grown by 124 million or $2.4 \%$ over the past year [7]. According to "Frost \& Sullivan", the global market for digital health products will reach $\$ 228$ billion by 2023 amid the introduction of such areas as mobile medicine, Internet of things, telemedicine, etc. These technologies help in the diagnosis and treatment of diseases, contribute to improving the quality, speed and efficiency of medical services in the process of realizing the human right to access the Internet in the health sector.

\section{Literature Review}

Both domestic and foreign researchers drew attention to the problems of legal regulation of human rights in the field of health care. So, D. Krylova (2017) studied the legal framework regarding the fourth generation of human rights in the context of the relationship of legal and moral norms [19]; Popovich T., \& Shavarin A. (2019) examined the content and list of components of the fourth generation of human rights [25]; Zaporozhyan, L. P., et. al. (2020) paid attention to the development of telemedicine[43]; Rudinsky, F. M. (2000) studied civil human rights [35]; O. Barabash, (2016) analyzed human rights that belong to the fourth generation, and justified the need to separate them into a separate group of human rights[3].

Also, foreign researchers studied legal issues regarding the search for information on the Internet about health and the functioning of the electronic health care system. Thus, Reglitz M. \& Rudnick A. (2020) point out that digital mental health services have become an effective alternative to personal treatment [34]. Nair A. (2006) drew attention to the problem of protecting children from the potential dangers of the Internet environment has led to various attempts to legislate content on the Internet. [23]. Powell, J. A., et. al. (2003) indicate that the Internet is increasingly being used to provide healthcare services [32]. Craan F., \& Oleske D.M. (2002) examined the various criteria needed to evaluate information on a medical website and pointed out that there are currently no standards for 
the validity of information published on the Internet [6]. Yigzaw, K. Y., et. al. (2020) points out that Internet search for health information strongly influences subsequent health-related behavioral decisions [42]. However, the relative human right to access the Internet has not been studied in the "concept of the right to health", which indicates the relevance of this study.

\section{Methodology and Research Methods}

In the process of this study, a set of methods and techniques of scientific knowledge was used, both general scientific (dialectical, logical) and special (documentary analysis, comparative legal). The use of which in conjunction made it possible to achieve the set goal of this work, to ensure the completeness and comprehensiveness of understanding the subject of this article, as well as the scientific reliability and persuasiveness of the results obtained. As a general scientific method, this work used the dialectical method of scientific cognition, which made it possible to carry out a systematic analysis of the legal regulation of the human right to access the Internet in the "concept of the right to health". With the help of the historical and legal method, the prerequisites for the emergence and formation of "telemedicine" as a method of providing medical services have been determined. With the help of the method of comparative jurisprudence, the methods of the logical method, the advantages and disadvantages of the introduction of "telemedicine" are revealed. The structure of Internet relations in the healthcare sector, the establishment of its object and subjects have led to the use of a number of scientific approaches: fundamental, organic unity of theory and practice, a combination of critical and rational (unity of a logical and systemic approach).

\section{The Human Right To Access the Internet in the Healthcare Sector as an Object of Legal Regulation}

The development of the Internet has raised topical issues of administrative and legal regulation of health care relations arising between Internet users and the state. In Ukraine, access to the Internet in the healthcare sector is not one that is guaranteed by the state on an equal basis with other human rights. That is, situations may arise when Internet access in the healthcare sector may be limited, especially among the population of rural areas.

The mechanism for ensuring human rights to access the Internet in the concept of "human right to health" forms legal principles, norms, legal guarantees, as well as conditions and requirements for the activities of state authorities, local governments, their officials, citizens, which together ensure compliance with, implementation and protection of the rights of citizens in the provision of medical services. The basis of the national legislation of Ukraine on human rights in access to the Internet in the concept of "human right to health" is the Constitution of Ukraine [5], which enshrines fundamental human rights, establishes a mechanism for their protection by regulating the activities of the highest bodies of state power and local self-government bodies

In accordance with Article 6 of the Fundamentals of Ukrainian Legislation on Health Care, every citizen of Ukraine has the right to health protection which implies: (1) the standard 
of living, including food, clothing, housing, medical care and social services and supplies, which is necessary to maintain human health; (2) environment safe for life and health; (3) qualified medical and rehabilitation assistance, including the free choice of a doctor and rehabilitation specialist, the choice of treatment methods, the choice of a health care institution; (4) reliable and timely information about the state of their health and the health of the population, including existing and possible risk factors and their degree; (5) legal protection against any illegal forms of discrimination related to health conditions; (8) compensation for harm caused to health; (9) appeal against unlawful decisions and actions of employees, institutions and health authorities; (10) informing about the available medical and rehabilitation services using telemedicine and telerehabilitation. Citizens of Ukraine who are abroad are guaranteed the right to health protection in the forms and volumes provided for by international treaties in which Ukraine participates. [10]. The realization of the human right to access the Internet in the healthcare sector in Ukraine is in the process of its development. So, in 2007, the Law of Ukraine "On the Basic Principles of Development of the Information Society in Ukraine for 2007-2015" was adopted, which directly outlines the main tasks of Ukraine in creating conditions for building an information society and ensuring computer and information literacy of the population. In Geneva in 2003, the Declaration of Principles "Building the Information Society - a Global Challenge in the New Millennium" was adopted. This act contains the main directions for the further development of the global information society. [4]. The concept for the development of the digital economy and society of Ukraine for 2018-2020 provides for the active development of digitalization. [27]. In 2019, WHO has developed a draft global digital health strategy 2020-2025. The main goal of this strategy is to strengthen health systems through the use of digital health technologies for consumers, health professionals, health professionals and the entire health sector to empower patients and realize the concept of health for all. [11]. So, human rights and freedoms and their guarantees determine the content and direction of the state's activities in the digital health of the population.

There is no single point of view in scientific sources regarding the understanding of the term "the right to health care" and "the human right to a person's access to the Internet in health care". Let's consider its components. In the legal literature, the term "health care" is considered in both broad and narrow sense. In the first version, it is a set of measures of a political, economic, legal, social, cultural, scientific, medical, sanitary-hygienic and antiepidemic nature, aimed at preserving, strengthening and restoring the physical and mental health of each person and the people of Ukraine as a whole, aimed at maintaining longterm active life of a person, providing him with medical assistance in case of loss or deterioration of health. In the narrow sense, the term "health care" should be understood as a system of legal, socio-economic and treatment-and-prophylactic measures and means aimed at preserving, strengthening and restoring the physical and mental health of a person. In accordance with Article 1 of the Law of Ukraine "Fundamentals of Ukrainian Legislation on Health Care", the term "health care" is a system of measures aimed at preserving and restoring physiological and psychological functions, optimal working capacity and social activity of a person with the maximum biologically possible individual life expectancy. Such activities are carried out by (1) state and local government bodies, their officials, health care institutions; (2) natural persons - entrepreneurs, and received a 
license for the right to carry out economic activities in medical practice; (3) medical and pharmaceutical workers, rehabilitation specialists, (4) public associations and citizens[10]. Based on the foregoing, the concept of "health care" should be understood as a system of legal, socio-economic and treatment-and-prophylactic measures and means, which are aimed at preserving, strengthening and restoring the physical and mental health of a person.

According to Art. 1 of the Law of Ukraine "On Telecommunications" the concept of "Internet" is a global information system of public access, which is logically connected by the global address space and is based on the Internet protocol defined by international standards. Also in this regulatory legal act the term "information" is defined as information presented in the form of signals, signs, sounds, moving or still images or in another way[30]. For example, the 1998 US "Children's Online Privacy Protection Act" refers to the Internet. The "Internet" is the interconnection of many computers and telecommunications facilities, including hardware and software, to form an interconnected international network of networks that is based on an internetworking protocol. The concept of "Internet" in the literature is usually called "computer network", or "information network", or "telecommunications network" and also apply to it such terms as: "virtuality", "virtual space", "virtual environment", "cyberspace" . So , Malakhov (2001) have a legal definition of the Internet, it consists of four interrelated elements: (1) The Internet is an information computer network, consisting of separate information computer networks, united on the basis of a single Internet protocol; (2) the Internet is an information space; (3) the Internet is the virtual habitat of the subjects of society, in which real social relations arise, develop and stop between the subjects of society, objectively existing in the real physical world; (4) the Internet is a set of informational public relations available in a virtual environment[20].

The Law of Ukraine "On Information" specifies the concept of "information". Information is any information and / or data that can be stored on tangible media and reflected in electronic form. In addition, in Ukraine, the right of everyone to information is enshrined at the constitutional level (Articles 31, 32, 34, 35 of the Constitution of Ukraine). In particular, part 2 of Art. 34 of the Constitution of Ukraine provides for the right of everyone to freely collect, store, use and disseminate information orally, in writing or in any other way - at his choice. According to UNESCO, information is "a universal substance that permeates all spheres of human activity, serves as a conductor of knowledge and thoughts, an instrument of communication, mutual understanding and cooperation, asserting stereotypes of thinking and behavior"[14]. Thus, every citizen of Ukraine has the right to freely collect, store, use and disseminate information orally, in writing or in any other way.

The majority of research experts consider the Internet space as an integral part of the information space, as a means of exchanging social information, as a carrier of a specific culture. It is necessary to support the point of view of I. M. Rassolov (2003) that the Internet law is currently permissible to be considered as "a new independent direction of legal science, including the theory of law and state." At the same time, "the subject of study of Internet law is a set of legal norms that regulate relations in the virtual space and contain prescriptions that relate to information activities on the Internet in general." Regarding the place of Internet law in the legal system, it can be considered as a complex legal institution, 
since in it, in certain cases, "the same social relations are regulated by the norms of various branches of law [33]. It should be noted that among specialists (primarily in the technical sphere) there is an extremely negative attitude towards the very idea of legal regulation of relations arising in the Internet environment. The Cyberspace Declaration of Independence was even circulated online (by John Barlow) [18], which proclaimed the right to freedom of the Internet space and the principle of non-interference of states in the regulation of Internet relations. There is a point of view of other authors-researchers that the Internet in general is not a subject of law, since it is not an international organization or a legal entity or any other organized structure in general. The Internet as a whole is not an object of law, since there is no single specific owner of the network, and in general there is no subject who would control a significant part of the network. In addition, the Internet as a whole is not a mass media, since the owner of the information resource does not take any active steps to deliver information to the consumer [2]. We support the author's point of view that the experience of legal regulation of social relations in the material world should be the basis for legal legal relations made using Internet technologies. But it should be aimed primarily not at providing additional powers to the state, but at ensuring basic human rights. The basis of such regulation should be the recognition of the principles of the priority of human rights and freedoms, adequate and justified state control, ensuring the choice of options that allow anonymity, minimizing the collection and processing of personal data [27].

So, regarding the legal regulation of public relations arising on the Internet in the healthcare sector, there are various scientific approaches. From a complete denial of the need for legal regulation of public relations on the Internet in the healthcare sector to the creation of special legislation that would regulate such relations. However, the emergence and rapid development of commercial relations on the Internet in the healthcare sector, the creation of conditions for free wide access of patients to electronic medical services, the problems of patient access for a personal appointment with a doctor, in connection with the introduction of quarantine measures to counter the COVID-19 pandemic, as well as active development of the provision of paid medical electronic services, the need to regulate the circulation of digital health technologies in the aspect of protecting the intellectual property rights of such technologies. The above factors indicate the appropriateness of the legal influence of the state on the regulation of public relations in the Internet of health care.

The structure of Internet relations in relation to the healthcare sector contains the following components: subjects, objects, subjective rights and obligations, information, technical means. From our point of view, legal relations on the Internet regarding the healthcare sector are a kind of information relations. Let us analyze the individual elements of the composition of Internet legal relations in the field of healthcare. So, the subjects are participants in the Internet health relations. The subjects include: (1) legal entities (providers, telecom operators; service providers that provide access to the Internet; host providers, developers of cross-border information networks) individuals (for example, citizens of Ukraine - consumers of medical information). About the object of Internet relations in the field of healthcare. In the theory of state and law, the object of legal relations is what the subjective rights and legal obligations of its participants are aimed at. In information law: the object of legal relations in the information sphere is information, 
or the result of the behavior of a participant in a legal relationship (provision, receipt, nondisclosure of information, etc.) [24]. Based on the foregoing, the object of Internet legal relations in the field of healthcare is what the subjective rights and legal obligations of its participants in this area are aimed at. This is information, or the result of the behavior of a participant in Internet relations directly related to medical information. In fact, such behavior of participants in Internet relations in the healthcare sector arises in relation to information or legally significant results of actions (inaction) with information (transmission, receipt, non-disclosure of medical information). This behavior must be regulated by the rule of law. It should be noted that subjective law in the Internet sphere is a type and measure of possible or permitted behavior of subjects of Internet relations guaranteed by the norms of law [33]. From our point of view, the human right to the Internet in the health sector is to ensure the actions of Internet users in the framework of Internet relations in the health sector, which are governed by the relevant legal norms.

There is no single list of the fourth generation of human rights in the literature. The fourth generation of human rights is the most criticized at the present stage of social and legal development of mankind. According to F. M. Rudinsky (2000), the rights of the fourth generation should protect a person from threats associated with experiments in the field of human genetic inheritance, that is, these are such human rights associated with cloning and other discoveries in the field of biology [35]. A. B. Vengerov (2000) calls the fourth generation the rights of mankind: the right to peace, nuclear safety, space, environmental, information rights, etc. [40]. We agree with those researchers who, in the fourth generation of human rights, single out the human right to access the Internet, namely D. Krylova (2017) [19]; Popovich T. \& Shavarin A. (2019) [31] and etc. Thus, human rights of the fourth generation are an independent legal category, corresponding to the modern interests of the individual and his needs. These rights are closely related to the physiological existence of a person, and depend on the development of medical technologies and society as a whole. They are a new phenomenon for all branches of law and require legislative consolidation and the creation of a clear regulatory mechanism. The right to access the Internet in healthcare is a fourth generation of human rights. Realization of this human right may include: (1) the right to free internet access in healthcare, (2) the right to free speech on the internet in healthcare, (3) the right to protect privacy and personal data on the internet in health care.

In international documents and also regulatory legal acts, some aspects of the human right to a person's access to the Internet in the field of healthcare are regulated. So, in order to comply with the standards of dissemination of information on the Internet in the field of health care, documents adopted by the UN, Council of Europe, OSCE and other international organizations are relevant. In this context, it should be pointed out that on July 6, 2012, the UN Human Rights Council recognized that the right to access the Internet should be protected and a resolution was adopted in which it noted that the same rights guaranteed for a person offline should be protected in online. In particular, this freedom of expression is applied regardless of borders and by any media chosen by a person in accordance with Article 19 of the Universal Declaration of Human Rights [39] and the International Covenant on Civil and Political Rights [16].

In the practice of the European Court of Human Rights, the issue of Internet access became the subject of a separate study back in 2012. In the case of Ahmet Yildirim v. 
Turkey, the ECHR Chamber judgment, case Ahmet Yildirim v. Turkey (application no. $3111 / 10$ ) [1] it was noted that "the right of unhindered access to the Internet should also be recognized". Okinawa Charter of the Global Information Society (July 20, 2000)), stated that the state must guarantee such conditions for the development of society, ensuring the creation of a global information society[25]. The Geneva Declaration of Principles (December 2003) identified the need to regulate the Internet, as "the Internet has become a publicly available global tool and governance of its use should be one of the main issues on the agenda of the information society". This international document declares only provisions on Internet governance, which is carried out by the state, but does not provide for a provision on granting everyone the right to access the Internet (it only states that "civil society has also played an important role in the affairs of the Internet, especially at the community level, and should continue to play such a role ")[4]. For example, Estonia recognized the right to access the Internet as an inalienable human right back in 2000, adding it to the legislative list of guaranteed public telecommunications services for its citizens. Finland set a minimum allowed connection speed of $1 \mathrm{Mb} / \mathrm{s}$ in 2009. Greece in 2011 amended the Constitution with Article 5A and made it an obligation to facilitate access to information provided online [9]. In 2015, the legislation of Ukraine registered the draft Law of Ukraine "On Amendments to the Civil Code of Ukraine (regarding ensuring the right of an individual to access the Internet)", which proposes to supplement Art. 302 Civil Code of Ukraine with the following lines: "An individual has the right to access the Internet. An individual's right to access the Internet cannot be restricted. Restricting access to certain data contained on the Internet is possible only on the basis of a court decision on the illegality of such data". From our point, this bill should be adopted. In 2016, the Council of Europe adopted the Internet Governance Strategy for the period 2016-2019. The Strategy is a multidisciplinary tool that covers issues related to content, services and devices connected to the Internet, including relevant aspects of its infrastructure and functioning that may affect human rights and fundamental freedoms. Particular attention is paid to ensuring online safety for everyone, and respecting and protecting the human rights of everyone in the digital world. [17].

\section{Electronic Health Care System in the Implementation of the Human Right to Access the Internet}

At the junction of Internet technologies, mobile devices, new methods of communication and the need to expand the availability of medical services, a new direction has emerged in the health care of Ukraine - Electronic health care system. The legal basis of (e-Health) and administrator (e-Zdorovya) is based on the following regulatory legal acts, as: Laws of Ukraine "On state financial guarantees of medical services for the population", "Fundamentals of Ukrainian legislation on health care", "On information", "On the protection of personal data", "On the protection of information in information and telecommunication systems", "On electronic documents and electronic document management." Thus, the procedure for the functioning of the electronic health care system is regulated by the Resolution of the Cabinet of Ministers of Ukraine dated April 25, 2018 No. 411 "Some issues of electronic health care" [36].

Leading UN health and telecommunications agencies, WHO and the International 
Telecommunication Union recognize the importance of development and collaboration on e-health. In modern conditions, the electronic health care system of Ukraine provides the conclusion of electronic declarations with family doctors, the issuance of electronic prescriptions under the "Affordable Medicines" program and electronic referrals, maintenance of an electronic medical record.

The concept for the development of e-health was approved by the order of the Cabinet of Ministers of Ukraine dated December 28, 2020 No. 1671-p e-Health understands as an ecosystem of harmonious and mutually acceptable information relations of all participants in the medical environment of the state, based on the cost-effective and safe use of information and communication technologies aimed at supporting the health care system , including medical services, preventive health surveillance, medical literature and medical education, knowledge and research. Also, the legal structure of "e-Health" is defined in Art. 1 of the Law of Ukraine "On state financial guarantees of medical care for the population", namely: the electronic health care system is defined as an information and telecommunication system that provides automation of medical services accounting and medical information management by creating, posting, publishing and exchanging information, data and documents in electronic form, in which includes a central database and electronic medical information systems, between which automatic exchange of information, data and documents is provided through an open program interface [28]. This Law discloses the content of the term "medical records" - as information on the patient's medical care or its results, set out in a unified form in accordance with the requirements established by law. The Resolution of the Cabinet of Ministers of Ukraine dated April 25, 2018 No. 411 "Some issues of e-health" defines the terms "central database", "electronic medical information system", "electronic cabinet", "electronic medical record". For example, an electronic cabinet is a personalized web page or interface with which the user, in accordance with his access rights, has the ability to create, view, exchange information and documents in the electronic health care system in accordance with this regulatory legal act; an electronic medical information system is an information and telecommunication system that allows you to automate the work of business entities in the healthcare sector, create, view, exchange information in electronic form, including with a central database (if connected).

The structure of e-health includes (1) a central database and (2) electronic medical information systems, between which an automated exchange of information, data and documents is provided through an open software interface. The task of e-health is to ensure the possibility of using electronic services by patients to exercise their rights under the program of state guarantees of medical services for the population, automating the accounting of medical services and managing medical information, introducing electronic document management in the field of medical services for the population under the program of medical guarantees[36].

eZdorovya - administers the e-Health Central Database and controls its development in Ukraine. In general, e-Health is a set of information services in the field of health care and everyday life of a person to maintain and strengthen health and create conditions for a quality life. eHealth covers the information space of various sectors of healthcare - medical practice, management of medical institutions, medical law, pharmaceuticals, information services for patients, etc. [22]. The e-Health system consists of (1) central and (2) peripheral 
components. The central component, which includes the national medical registers of the Ministry of Health of Ukraine, classifiers, data storage and interoperability, is a specialized software product for obtaining the necessary information from medical institutions in the field. All medical institutions, regardless of the form of ownership or type of management, which will provide services to patients for budgetary funds, as well as family doctors will be required to register in the central component of e-Health of the Ministry of Health of Ukraine and report on the volume and quality of medical care provided[22].

Regarding "Helsi". So ," Helsi "is an electronic medical system, created and cooperates with patients, doctors, public and private medical institutions, pharmaceutical companies, insurance companies. The goal of Helsi is to ensure that any doctor, public or private, has the opportunity to easily, efficiently and affordably provide his services, and the patient, accordingly, quickly and comfortably realize his rights and needs. More than 2 million users sign up to the doctor every month through the Helsi system. Through the system, 15.6 million declarations have already been concluded between doctors and patients in Ukraine. The product is used by more than 16,000 doctors throughout Ukraine. The system works in more than 1400 medical institutions[12].

\section{Telemedicine as an Opportunity to Realize the Human Right to Access the Internet: forms And Concepts, Development of Legislation}

With the development of the Internet in the health care of Ukraine, telemedicine technologies received a new stage of development. For the first time, the use of telemedicine on a global scale was identified in Resolution WHA58.28 "eHealth / eHealth". In the International Society for Telemedicine and eHealth, the term "telemedicine" is defined as the use of electronic information and communication technologies to provide and maintain health care when participants are at a distance from each other. WHO has presented its definition of "telemedicine". Telemedicine is the provision of healthcare services in an environment where distance is critical, by healthcare professionals using information and communication technologies to exchange relevant information for the diagnosis, treatment and prevention of diseases and injuries, conduct research and assessments, and provide continuing education for healthcare professionals. for the improvement of public health and the development of local communities [41]. In accordance with Article 1 of the Law of Ukraine "Fundamentals of Ukrainian Legislation on Health Care" Telemedicine is a set of actions, technologies and measures used in the provision of medical care using remote communications for the exchange of information in electronic format [10]. The main objectives of telemedicine are: (1) ensuring the provision of medical care to the patient when distance is a critical factor in its provision; (2) maintaining medical secrecy and confidentiality, the integrity of medical information about the patient's health; (3) creation of a unified medical space; (4) assistance in improving the quality of care and streamlining the organization and management of healthcare; (5) formation of systematic approaches to the implementation and development of telemedicine in the health care system [26]. The use of telemedicine produces positive results for both patients and doctors. For patients, it becomes possible to conduct remote consultations, consultations (teleconferences) by narrow specialists in geographically remote medical institutions, reduce the time of examination, accelerate the 
transfer of information about the results of examinations between various specialized clinics without the need to transport the patient (especially in emergency conditions) [43]. The provision of medical services with the use of telemedicine is carried out through the use of the following forms: (1) telemedicine consultation (2) telemedicine consultation (3) telemetry (4) home teleconsultation (5) performing medical manipulations and operations. When they are carried out, using electronic and software tools, they can be recorded, including audio, video, as well as the parameters of medical equipment (Article 35) [10]. These terms should be understood as: (a) telemedicine consultation is a process of discussing a clinical case using secure telecommunications and other computer information, software and hardware in order to make the doctor the most optimal and timely clinical decision; (b) telemonitoring - the process of a single or extended examination of a patient using electronic diagnostic devices in real time or periodically transmitting data to a consultant for the purpose of accumulating, analyzing medical information on physiological function and taking appropriate actions to provide medical care; (c) telemetry - a set of technologies that allow remote measurement, collection and transmission of information about the performance indicators (physiological functions) of the patient's body; (d) home teleconsultation - the process of constant monitoring of the health of an individual patient, family or small group, which includes periodic sessions of telemonitoring, telemedicine consultation[29].

About the development of telemedicine. In 2007, the State Clinical Scientific and Practical Telemedicine Center of the Ministry of Health of Ukraine was established. Since 2009, this Center has been implementing a project to create a telemedicine network in Ukraine, thanks to which telemedicine consulting and the exchange of experience of doctors have been established. During 2012-2014, only 9 healthcare institutions implemented telemedicine projects. In October 2015, the Ministry of Health of Ukraine issued Order No. 681 "On Approval of Normative Documents on the Use of Telemedicine in the Healthcare Sector", which spelled out the Procedure for organizing medical care at the primary, secondary, tertiary levels with the use of telemedicine. The regulation on the telemedicine office was approved [26]. In September 2016, the Cabinet of Ministers of Ukraine made changes to the "List of paid services provided in public health institutions and higher medical educational institutions." The list of a number of services includes medical services using telemedicine. In particular, laboratory, diagnostic and advisory services for citizens, medical assistance to patients at home. In November 2017, the Ukrainian parliament adopted the law "On improving the availability and quality of medical care in rural areas", one of the directions is the introduction of modern technologies using telemedicine.

The need for the development of telemedicine is evidenced by the order of the Ministry of Health of Ukraine dated 03.23.2020 No. 698 "Temporary measures in healthcare institutions in order to ensure their readiness to provide medical care to patients with acute respiratory disease COVID-19 caused by the SARS-CoV-2 coronavirus." In particular, the order recommends to health care institutions: to ensure the temporary termination of planned hospitalizations of patients; take measures to increase the proportion of medical care using telemedicine[38]. In March 2020, the telemedicine platform "doctor-patient" Telemed24, free for patients, began to work actively in Ukraine. The patient can, through the Medcard24 mobile application, sign up for an online consultation with a doctor, which 
takes place in the format of a telephone or video link. Telemed24, an online patient consultation platform, transfers data to the Electronic Health System of Ukraine (eHealth). The Telemed24 telemedicine platform allows you to book a patient for an online consultation (even a phone call) to a doctor at a specific time; conduct a video chat, prescribe treatment, write an electronic prescription, send for diagnostics, set up a calendar for monitoring objective and subjective health indicators, as well as record it in an electronic medical record and send an episode to eHealth; remotely conclude a declaration with a patient who needs medical assistance[13].

The key issues of telemedicine regulation include the protection of medical information, the responsibility of all parties to this process, licensing and the status of a consultant, informed consent of the patient, and logging of telemedicine activities. These aspects have national characteristics, are regulated by various regulatory legal acts, both at the state and regional levels [21]. Also, when providing telemedicine services, the preservation of personal, medical secrets and other secrets provided for by law, as well as the confidentiality of personal data, must be ensured. When introducing telemedicine, it is necessary to solve the following tasks: 1) determining the direction of medical consultations when using telemedicine; 2) the choice of the legal framework; 3) development of a security policy with the definition of telemedicine participants, the distribution of their rights and the corresponding cryptographic means of protecting information; 4) selection or development of new hardware and software, taking into account the characteristics defined above; 5) development of a system for the selection of experts; 6) testing and verification of the created telemedicine[8]. The next problem concerns telemedicine hardware and software. In particular, it is necessary to take into account their cost, that is, they should be economically profitable not only for commercial, but also for public medical institutions. In addition, the firmware should provide an interface for users, including doctors and patients.

\section{Conclusions}

The modern concept of the human rights to Internet access in health care is in the process of development at the national level. In international law, the human right to access the Internet is understood as one of the inalienable human rights. Securing the right to access the Internet at the level of the Constitution of Ukraine is a necessity. Securing the right to access the Internet in the field of health care in the legislation of Ukraine, provided by the state, will contribute to the implementation of other constitutional rights and freedoms of man and citizen. The right to access the Internet should be considered as a derivative right within the framework of the "right to health" and provided for in Article 6 of the Fundamentals of Ukrainian Legislation on health care. The right to access the Internet in health care is closely related to the right to free access and freedom of information, as well as the right to personal data protection.

In Ukraine, such systems as "E-Zdorovya" and "e-Health", as well as "Helsi", which includes the use of electronic prescriptions and medical records, electronic medical histories of patients, are being actively implemented. These processes require additional regulations that will regulate the development of such healthcare technologies in accordance with international standards. e-Zdorovya - administers the e-Health Central 
Database and controls its development in Ukraine. The e-Health system consists of (1) central and (2) peripheral components. E-Health includes (1) a central database and (2) electronic health information systems. "Helsi", is an electronic medical system that cooperates with patients, doctors, public and private medical institutions, pharmaceutical companies, insurance companies.

The possibility of exercising the right to access the Internet in the implementation of medical services is the introduction and development of telemedicine in Ukraine. Telemedicine in Ukraine is now only at the stage of formation. The right to medical services with the use of telemedicine is exercised in telemedicine offices operating as part of health care institutions in Ukraine. Telemedicine services are provided through the use of the following forms: (1) telemedicine consultation; (2) telemedicine council; (3) telemetry; (4) home teleconsultation; (5) performing medical procedures and operations. The legal aspects remain unresolved regarding the development of a security policy and appropriate cryptographic means of protecting information, especially the protection of personal data, ensuring and maintaining personal, medical secrets, protecting intellectual property rights on the Internet, and there is also a need to develop legal mechanisms of state control over activities private companies - operators of the Medical Information System of Ukraine.

\section{References}

Ahmet Yildirım v. Turkey - 3111/10 Judgment 18.12.2012. European Convention on Human Rights. Information Note on the Court's case-law No. 158 December 2012. file:/ / C:/Users/1722/Downloads/002-7328.pdf

Andreev B.V. \& Vagonova E.A. (2001). Law and the Internet. Moscow, Institute of International Law and Economics named after A.S. Griboyedov. 26 p.

Barabash, O. (2016). Fourth generation of human rights: general characteristics. Bulletin of Lviv Polytechnic National University. Series: Legal Sciences , (837), 213-217.

Building the Information Society - a Global Challenge in the New Millennium: Declaration of Principles (2003). URL: https://zakon.rada.gov.ua/laws/show/995_c57

Constitution of Ukraine: Law of Ukraine No 254к/96 of 28 June, 1996. Information of the Verkhovna Rada of Ukraine. № 30. Art. 141.

Craan, F., \& Oleske D.M. (2002). Medical information and the Internet: do you know what you are getting? $J$ Med Syst. 26(6):511-8. doi: 10.1023/a:1020240625200.

Digital 2020: annual global survey from We Are Social и Hootsuite. URL: https://exlibris.ru/news/digital2020-ezhegodnoe-globalnoe-issledovanie-ot-we-are-social-i-hootsuite

Dubchak, L. O. (2017). Telemedicine: current state and prospects of development. Information processing systems, (1), 144-146.

Dvorovy M. G. (2019) Are we going to talk about the right to the Internet in Ukraine? Media detector. URL: https://detector.media/infospace/article/ 172446/2019-11-15-chi-budemo-mi-govoriti- propravo-na-internet -v-ukraini

Fundamentals of Ukrainian legislation on health care: Law of Ukraine No. 2801-XII of 19 November, 1992. Information of the Verkhovna Rada of Ukraine.1993. № 4. Art. 19.

Global strategy on digital health 2020-2025. World Health Organization. URL: https://www.who.int/docs/default-source/documents/gs4dhdaa2a9f352b0445bafbc79ca799dce4d.pdf

HELSI - information system for patients: URL: https://helsi.me/about

History of telemedicine. URL: https://telemed24.ua/articles/istoriya-rozvytku-telemedycyny

Iakovenko, M. (2011). Information space: philosophical aspects of concept formation. URL: http://ena.lp.edu.ua/bitstream/ntb/ 10307/1/4.pdf 
Increasing the availability of medical technologies and innovations. At the intersection of healthcare, intellectual property and trade (2013). World Health Organization, World Intellectual Property Organization and World Trade Organization. URL: https://www.wipo.int/edocs/pubdocs/ru/wipo_pub_628.pdf

International Covenant on Civil and Political Rights of 16.12.1966. URL: https://zakon.rada.gov.ua/laws/show/995_043\#Text

Internet Governance - Council of Europe Strategy 2016-2019. URL: https://search.coe.int/cm/Pages/result_details.aspx?ObjectId=09000016805c1b60

John Perry Barlow A Declaration of the Independence of Cyberspace. URL: https://projects.eff.org/ barlow/Declaration-Final.html

Krylova, D. (2017). The fourth generation of human rights in the context of the relationship of legal and moral norms. Jurnalul juridic national: teorie și practică. 2(24). 26-30.

Malakhov S. V. (2001) Civil law regulation of relations in the global computer network Internet: author. ... dis. Cand. jurid. Sciences Moscow: Moscow Open Social University, 2001.21 p.

Mozheiko, V. Ch. (2018) Telemedicine: from the past to the present, development prospects in the provision of primary health care. Military medicine. 1. 108-114.

Myskevich T. (2019) Development of eHealth in the context of transformation of the health care system of Ukraine Public opinion on lawmaking. 16 (181). 18-23. URL: http://nbuviap.gov.ua/images/dumka/2019/16.pdf.

Nair, A. (2006). Mobile phones and the internet: Legal issues in the protection of children. International Review of Law, Computers \& Technology, 20:1-2, 177-185, DOI: 10.1080/13600860600579779

Ogorodov D.V. (2002) Legal relations in the information sphere: Thesis PhD. Moscow, 25 p.

Okinawa Charter for the Global Information Society (Okinawa, 22 July 2000). URL: https://zakon.rada.gov.ua/laws/show/998_163\#Text

On approval of normative documents on the use of telemedicine in the field of health care: order of the Ministry of Health of Ukraine 19.10.2015 № 681. URL: https://zakon.rada.gov.ua/laws/show/z1400-15\#Text

On approval of the Concept for the Development of the Digital Economy and Society of Ukraine for 20182020 and the approval of an action plan for its implementation: by order of the Cabinet of Ministers of Ukraine dated January 17, 2018 No. 67-r. Official Bulletin of Ukraine. 2018. No. 16.Art. 560.

On state financial guarantees of medical care: Law of Ukraine of 19.10.2017 № 2168-VIII. Information of the Verkhovna Rada. 2018. № 5. Art.31.

On the introduction of telemedicine in health care facilities: Order of the Ministry of Health of Ukraine 26.03.2010 № 261. URL: https://zakon.rada.gov.ua/rada/show/v0261282-10\#Text

On Telecommunications: Law of Ukraine No. 1280-IV of 18 November, 2003. Information of the Verkhovna Rada of Ukraine. 2004. № 12. Art. 155. URL: https://zakon.rada.gov.ua/laws/show/128015\#Text

Popovych, T. \& Shavaryn A. (2019). The essential content of the fourth generation of human rights. Entrepreneurship, Management and Law. 12. 266-271. URL: http://pgpjournal.kiev.ua/archive/2019/12/50.pdf

Powell, J. A., Darvell, M., \& Gray, J. A. (2003). The doctor, the patient and the world-wide web: how the internet is changing healthcare. Journal of the Royal Society of Medicine, 96 (2), 74-76. https://doi.org/10.1258/jrsm.96.2.74

Rassolov, I. M. (2003) Law and the Internet. Theoretical problems. Moscow, Norma. 251 p.

Reglitz, M. \& Rudnick, A. (2020). Internet access as a right for realizing the human right to adequate mental (and other) health care. International Journal of Mental Health, 49:1, 97103. DOI: $10.1080 / 00207411.2020 .1727019$

Rudinsky , F. M. (2000) Civil human rights: general theoretical questions. Law and life. 31, 15-18.

Some issues of the electronic health care system: the resolution of the Cabinet of Ministers of Ukraine of April 25, 2018 № 411. Official Bulletin of Ukraine. 2018. № 46. Art. 1604.

Sukhorolsky, P.M. (2013). The right to anonymity as an essential element of human rights. Legal informatics, (1), 39-48.

Temporary measures in health care facilities to ensure their readiness to provide medical care to patients with acute respiratory disease COVID-19 caused by coronavirus SARS-CoV-2: order of the Ministry of Health of Ukraine dated 23.03.2020 № 698. URL: https://moz.gov.ua/uploads/3/19644dn_23032020_698_dod.pdf 
Universal Declaration of Human Rights of December 10, 1948. URL: https://zakon.rada.gov.ua/laws/show/995_015\#Text

Vengerov A.B. (2000). Theory of state and law: a textbook for law schools. M .: Jurisprudence, $478 \mathrm{p}$.

WHO. A health telematics policy in support of WHO's Health For-All strategy for global health development: report of the WHO group consultation on health telematics, 11-16 December, Geneva, 1997. Geneva, World Health Organization, 1998.

Yigzaw, K. Y., Wynn, R., Marco-Ruiz, L., Budrionis, A., Oyeyemi, S. O., Fagerlund, A. J., \& Bellika, J. G. (2020). The Association Between Health Information Seeking on the Internet and Physician Visits (The Seventh Tromsø Study - Part 4): Population-Based Questionnaire Study. Journal of medical Internet research, 22(3), e13120. https://doi.org/10.2196/13120

Zaporozhyan, L. P., Terenda, N. O., Litvinova, O. N., Panchishin, N. Y., \& Fesh, M. S. (2020). The need for the development of Ukrainian telemedicine in modern conditions. Bulletin of Social Hygiene and Health Protection Organization of Ukraine, (2), 65 -71. URL:https://doi.org/10.11603/16812786.2020.2.11413 